\title{
Improving Observing Skills of High School Students Through Guided Inquiry Model
}

\author{
Sahnaz, S. ${ }^{1}$. Harlita ${ }^{2}$, Ramli, M. ${ }^{3}$ \\ ${ }^{1,2,3}$ Department of Biology Education, Faculty of Teacher Training and Education, \\ Universitas Sebelas Maret, Surakarta, Indonesia. \\ corresponding email: $\underline{\text { mramlim@staff.uns.ac.id }}$
}

\begin{abstract}
Observation skill is one of the fundamental science process skills should be acquired by students at the elementary school. In fact, due to the lack of experiences of observation, high school students in the observed class showed inadequate observation skills. To solve the problem, a three cycles-collaborative action research was conducted in biology through the implementation of guided inquiry learning integrated with a series of observation activities. The participants were 30 students of grade eleven of one public high school in Karanganyar, Indonesia. Six indicators of observation skills were used to assess the performance of students. At the pre-cycle, students were grouped into three based on the academic achievement, i.e. high skills (HS), moderate skills (MS) and low skills (LS). After three iterative cycles, all indicators have increased significantly, and students from LS increased better than the other two.
\end{abstract}

Keywords: observation skills; guided inquiry; classroom action research; biology

DOI: $10.20961 /$ ijpte.v\%vi\%i.16608 


\section{INTRODUCTION}

Observing skill is a part of the science process skills, which is a series of activities to collect data about an object using all the senses (Karamustafaoğlu, 2011). Observing skill is the most basic skill that bridges the mastery of higher level science process skills (Stone, 2014). Observing skills is included skills to using several senses, identifying the differences and similarities of an object, using the tools to obtain data, and searching for the relevant data (Rankin, 2006).

Observing is a broad activity, not only using the sense of sight to collect data, but also using other sensory devices such as hearing, smell, taste, and touch (Simsek \& Kabapinar, 2010). Using tools is also required in observing activities to help and improve the quality of the obtained data (Rustaman, 2003).

In the preliminary study, researchers have identified that students' observing skills were weak. It was shown from several instructional processes delivered by tutor teacher, and also when the student teacher taught in the class. To check the level of the students' observing skill in details, the researcher along with the tutor teacher, made an assessment of observing skills according to the indicators proposed by Rankin. The results were: On the skill of identifying differences and similarity, students scored 45.83. It means that the students could identify the differences and similarities of an object based on appearances or facts. The skill to use multiple senses to observe rated in average as 45.83 , which means the students were quite masterful to use multiple senses as a technique to observe. The results on the aspect of the skill to identify the detailed differences got a low average score of 4.17. This suggests that the students could not identify the distinctive features and details of the object. On the skill to classify the differences and similarities scored 25, or the students were not proficient enough to grouping the differences and similarities based on the results of the observation. On the skill of using the correct tools to aid the observation, students scored an average of 4.17. It shows that the students only mentioned the general characters of the object without adding more explanations, such as the size, the typical shape, and the colour of the object. Collecting the relevant data scored 29.17, or the students were not proficient enough to decide what data that should be collected related to the observed object.

Factors that are affecting students' poor performance in observing skills are due to lack of training and observing activities in the classroom. The activities usually done in the biology class are lecturing, discussion, memorising in front of the class, and a quiz to recall the concepts learned in the previous topics. The teacher assumed that direct instructional learning and memorisation drills would have a better impact on students' understanding and recalling abilities related to the biological concepts.

Another factor that causes the poor performance in observing skills were the lack of students' opportunities to train this skill. Teacher is rarely conducting practicum. However, when a class has practicum, students fill in the task in the worksheet by finding the answers in the textbook. Again, students do not do observation. In addition, the learning process which is far from active and 
contextual learning, and minimum laboratory-assisted learning might also be factors.

How to improve the observing skills of the students? The learning activities have to be designed to give students opportunities to hone their observing skills. Learning activities that supposed to be capable of accommodating the students to observe actively and focus on experiment and discussion activities. It can stimulate the students to more active and play more direct role in finding information, improving skills for gathering proper facts or information, and using different kind of senses and proper tools, so it can improve students' observing skills (Rankin, 2006).

Guided inquiry brings the learners to discover their knowledge through inquiry activities with guidance from the teacher (Kuhlthau, et al., 2007). Sutman et al. (2008) added that guided inquiry can be done by giving the students the opportunity to define the procedures, interpret the results, and draw the conclusions independently. The role of teachers in the meaning of "guided" can be determined at three checkpoints of the activities; when defining the problems, when determining the steps of activities and procedures of investigation, and when drawing the conclusion or reconstruction of the concepts.

The main feature of the guided inquiry learning model is the process of searching and finding. The role of the students in this learning model is to search and find the answers and comprehension to the problems related to the subject, while the teacher acts as a facilitator and helps students to learn (Bodrova \& Leong, 2015). The syntaxes of the guided inquiry learning were: 1 ) orientation, 2) formulate the problems, 3) formulate the hypotheses, 4) collect the data, 5) hypothesis testing, and 6) formulate the conclusions that train students to draw conclusions and communicate the results of the experiment (Sutman, et al., 2008).

Based on the above descriptions, we applied the guided inquiry as the learning model to improve the observing skills of the students through classroom action research. The guided inquiry model was selected due to its effectiveness in allowing students to search the information through observation, finding the problems, doing an experiment, and at the end developing a conclusion. Each stage of inquiry brings students to train their scientific process skills, including the observing skills. Various researchers suggested that the interventions of guided inquiry model in biology learning can improve students' skills to build the information from the facts and the data obtained from observations (Riyadi, Prayitno, and Marjono, 2015; Nurochmah 2008; Ambarsari and Santosa, 2013; and Sidiq, et al. , 2012). Guided inquiry model was expected to aid the students in developing science process skills, especially observing skills. The research question of this study is: "Is the observing skill of the eleventh graders could be improved by the application of guided inquiry learning?"

\section{METHODOLOGY}

The study was conducted on September to November 2016, on the topic of the musculoskeletal system, and the circulatory system. The subjects of the study were 30 eleventh graders of an Immersion Program class, consisted of 12 boys 
and 18 girls with various academic capabilities. The academic capabilities were rated from the regular assessment score in biology. The result of the test divided the student into three groups, 1) High skills or HS (85-90), 2) Moderate skills or MS (80-84), and 3) Low skills or LS (75-79). The Immersion Program class is a bilingual class using English and Indonesian language as the language of instruction.

The research design was compiled according to spiral cycle method of Kemmis et al. (Kemmis \& Mc Taggart, 2005) consists of the reflection of initial conditions before action; constructing the plan for lesson activities; implementation of the lesson plan; data collection and analysis; and reflection to determine the shortcomings and improvements that will be applied in the next cycle. These steps take place in a spiralling cycle.

Reflection of the initial observation result includes the analysis of students' observing skill, investigation of the root of the weakness of students' observing skill, and review of the literature to decide problem-solving approach. In this study, was decided guided inquiry approach, and observation activities were facilitated through experimentation.

The data taken during the research was the students' observing skill. Observations of the performance of the students' observing skills were conducted by three observers. The observers were equipped with the checklists of observing skill indicators that compiled according to Rankin (2006). The observers mark with the tick $(\sqrt{ })$ on the appropriate descriptors on the observation sheets and write a detailed description of the student's activities during the lesson. The results of the data analysis were used as a reflection for improvement of the next cycle. The rubric for observation of students' observing skill and the scoring system are available in Table 1 and Table 2.

Students were asked to observe the object prepared by the teacher, and the result of observation is to fill in the worksheet. By collecting data and information needed, students be trained routinely to observe appropriately and expected to improve their skills. In each cycle, the teacher provided students with different objects, and also guided questions in the student's worksheet.

The research was planned for three cycles with the target of students' observing skill could be improved to achieve good category (score 3). Observing skill was categorized as good when the students have been able to: find the differences and similarities of the observed object, using multiple senses for observation, identifying the detailed differences of the observed object, identifying whether the objects were more similar or the different, using proper tools to aid observation, and collecting the relevant data.

The teaching topic in three research cycles was the human circulation system. In the first cycle, the subtopic was about blood and blood components, in the second cycle discussed the blood type and blood transfusion. While in the third cycle the topic is about heart and heart pressure. All activities have followed the steps of guided inquiry learning, i.e. 1) orientation, 2) formulate the problems, 3) formulate the hypotheses, 4) collect the data, 5) hypothesis testing, and 6) formulate the conclusions added with practicum and observation. Teacher-guided 
the students on constructing the research problem on the syntax 2 and provided the instruction on practicum procedures (syntax 4). While students developed a conclusion.

Table 1. The Rubric of Students' Observing Skill (Adopted from Rankin, 2006)

\begin{tabular}{|c|c|c|}
\hline $\begin{array}{c}\text { Indicators of } \\
\text { Observing Skills }\end{array}$ & $\begin{array}{c}\text { Level of } \\
\text { Achievement }\end{array}$ & Description \\
\hline $\begin{array}{l}\text { Identify the } \\
\text { obvious }\end{array}$ & 4 & $\begin{array}{l}\text { The student was able to identify all the differences and } \\
\text { similarities of the observed object. }\end{array}$ \\
\hline \multirow{4}{*}{$\begin{array}{l}\text { differences and } \\
\text { similarities of the } \\
\text { observed object. }\end{array}$} & 3 & $\begin{array}{l}\text { The student was able to identify three differences and } \\
\text { similarities of the observed object. }\end{array}$ \\
\hline & 2 & $\begin{array}{l}\text { The student was able to identify two differences and } \\
\text { similarities of the observed object. }\end{array}$ \\
\hline & 1 & $\begin{array}{l}\text { The student was able to identify one difference and } \\
\text { similarity of the observed object. }\end{array}$ \\
\hline & 0 & $\begin{array}{l}\text { The student was unable to identify the differences and } \\
\text { similarities of the observed object. }\end{array}$ \\
\hline \multirow{3}{*}{$\begin{array}{l}\text { Use multiple } \\
\text { senses for } \\
\text { observation. }\end{array}$} & 4 & The student uses two or more appropriate senses to observe. \\
\hline & 2 & Student use only one appropriate sense to observe. \\
\hline & 0 & $\begin{array}{l}\text { The student did not use the appropriate senses for } \\
\text { observation. }\end{array}$ \\
\hline \multirow{5}{*}{$\begin{array}{l}\text { Identify the } \\
\text { detailed } \\
\text { differences of the } \\
\text { observed object. }\end{array}$} & 4 & $\begin{array}{l}\text { The student was able to identify all the detailed differences } \\
\text { of the object. }\end{array}$ \\
\hline & 3 & $\begin{array}{l}\text { The student was able to identify three detailed differences of } \\
\text { the object. }\end{array}$ \\
\hline & 2 & $\begin{array}{l}\text { The student was able to identify two detailed differences of } \\
\text { the object. }\end{array}$ \\
\hline & 1 & $\begin{array}{l}\text { The student was able to identify one detailed difference of } \\
\text { the object. }\end{array}$ \\
\hline & 0 & $\begin{array}{l}\text { The student was unable to identify the detailed differences } \\
\text { of the object. }\end{array}$ \\
\hline \multirow{5}{*}{$\begin{array}{l}\text { Identify whether } \\
\text { the object is more } \\
\text { similar or } \\
\text { difference }\end{array}$} & 4 & $\begin{array}{l}\text { The student determines whether the objects have more } \\
\text { similarities or differences by mentioning all the similarities } \\
\text { and differences. }\end{array}$ \\
\hline & 3 & $\begin{array}{l}\text { The student determines whether the objects have more } \\
\text { similarities or differences by mentioning two similarities and } \\
\text { differences. }\end{array}$ \\
\hline & 2 & $\begin{array}{l}\text { The student observes two similarities and differences of the } \\
\text { objects. }\end{array}$ \\
\hline & 1 & $\begin{array}{l}\text { The student observes one similarity and differences of the } \\
\text { objects. }\end{array}$ \\
\hline & 0 & $\begin{array}{l}\text { The student does not observe similarity and difference of the } \\
\text { objects }\end{array}$ \\
\hline \multirow{5}{*}{$\begin{array}{l}\text { Use the } \\
\text { appropriate tools } \\
\text { to aids the } \\
\text { observation }\end{array}$} & 4 & The student was able to use tools to obtain all required data \\
\hline & 3 & $\begin{array}{l}\text { The student was able to use an appropriate tool to collect } \\
\text { one information about the objects. }\end{array}$ \\
\hline & 2 & The student was able to install the tool. \\
\hline & 1 & The student was able to prepare the equipment. \\
\hline & 0 & The student was unable to use the appropriate tool. \\
\hline \multirow[t]{3}{*}{$\begin{array}{l}\text { Collecting } \\
\text { relevant data }\end{array}$} & 4 & $\begin{array}{l}\text { The student was able to collect all data and reasons } \\
\text { appropriately }\end{array}$ \\
\hline & 3 & $\begin{array}{l}\text { The student was able to collect three data and reasons } \\
\text { appropriately }\end{array}$ \\
\hline & 2 & The student was able to collect two data and reasons \\
\hline
\end{tabular}




\begin{tabular}{ll}
\hline 1 & $\begin{array}{l}\text { appropriately } \\
\text { The student was able to collect one data and reason } \\
\text { appropriately }\end{array}$ \\
& $\begin{array}{l}\text { The student was unable to collect data and reason } \\
\text { appropriately }\end{array}$ \\
\hline
\end{tabular}

Table 2. The Scoring Guidelines

\begin{tabular}{lc}
\hline \multicolumn{1}{c}{ Level of Achievement } & Score \\
\hline 4 (Very Good) & 4 \\
3 (Good) & 3 \\
2 (Fair) & 2 \\
1 (Low) & 1 \\
0 (Very Low) & 0 \\
\hline
\end{tabular}

Maximum Score $=4$ (highest score) $* 6$ (total of indicators $)=24$

\section{RESULT AND DISCUSSIONS}

The results of the research showed that the students' observing skill based on grouping of students' skills were presented in Table 4, Table 5, and Figure 1.

Table 4. Grouping of The Student's Observing Skill

\begin{tabular}{llccc}
\hline Category & \multicolumn{1}{c}{ Students' Number } & \multicolumn{3}{c}{ Students } \\
\cline { 2 - 5 } & & Boys & Girls & Total \\
\hline HS & $1,2,6,12,14,18,23,27,28$ & 3 & 6 & 9 \\
MS & $3,5,7,9,12,15,16,20,21,24,25,26$, & 7 & 6 & 13 \\
LS & 29 & 2 & 5 & 7 \\
\hline
\end{tabular}

Table 5. Average Scores of Pre-cycle and Post-cycle Tests

\begin{tabular}{lccc}
\hline \multirow{2}{*}{ Category } & \multicolumn{3}{c}{ Average Scores on the Cognitive Tests } \\
\cline { 2 - 4 } & Pre-cycle & Post-cycle & Differences \\
\hline HS & 86,42 & 87,63 & 1.21 \\
MS & 82,12 & 85,28 & 3.16 \\
LS & 77,58 & 85,01 & 7.43 \\
\hline
\end{tabular}

Students' observing skills from pre-cycle to the last cycle shows various improvement in each group. The HS group was increased by 53.25, the MS group was increased by 61.61, while the LS group was increased to 67.76. The LS group is the group with the greatest increase. The students from the LS group gained more improvements because the teachers conditioned the LS group students as learning centres, ranging from group leaders, to demonstrate the use of the tools, to present the conclusion in front of the class. The LS students also experienced an improvement in concept comprehension, compared with MS and HS students whose have been understood the concept from the beginning, so the observing skill of the LS increased the most. In addition, heterogeneous grouping by combining HS students with LS students can help LS students to develop a better understanding. 
Learning activities on the pre-cycle were focused on the learning of the musculoskeletal system on the structures of the bones. Students have studied the structures of the bones and were expected to distinguished the structures of the compact bone and the cartilage. The object observed by the students were the chicken bones (as the representative of cartilage) and the human bone specimens (representative of compact bone). Learning takes place in the classroom; the learning activities were simple experimentation and discussion. Students in groups were asked to observe and record their observations on their worksheets. The result of measurement of students' observing skill on pre-cycle became the basis of students grouping. HS group was the students with average scores of observing skill were 33.79 (9 students), MS group was the students with the score of 25 (13 students), and LS was the student with average scores of 16.67 (7 students).

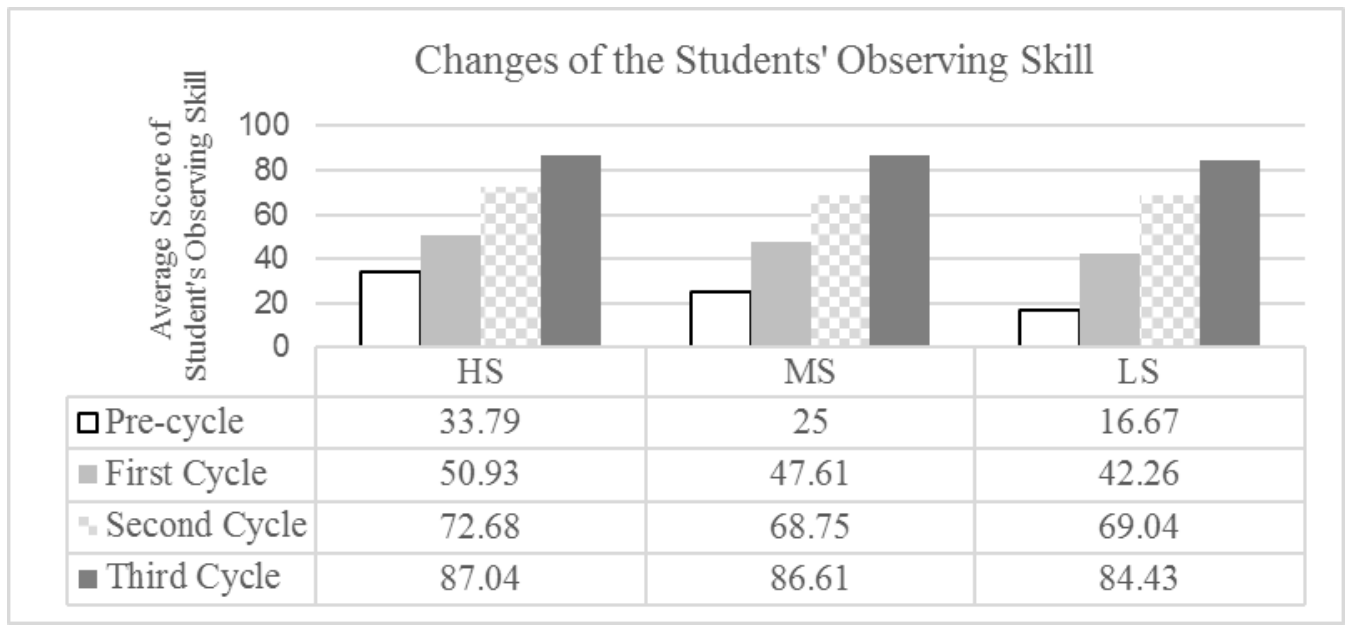

Fig. 1: Changes in the Students' Observing Skill Over the Cycles of the Learning

Students of LS group were able to identify only 1 out of 4 obvious differences and similarities between observed object, which was the bone color, use one appropriate sense to observe, unable to identify any detailed differences in the object, cannot determined whether the object is more similar or different, unable to use the microscope, and only able to collect two relevant data. While the HS group were able to identify 2 out of 4 differences and similarities of the object, which are the bone colour and endurance, use one appropriate sense to observe, able to identify one detailed difference in the object, cannot determine whether the object is more similar or different. They also able to set up the microscope but are not focusing on the object, and finally, those students were able to collect three relevant data.

The main factor that caused students' poor observing skills in the pre-cycle was the lack of students 'ability to use the microscopes were inadequate, so the students could not collect the correct and relevant data. Students do not understand what activities that needed to be conducted during observation (without instruction and guidance from teachers). McNeill \& Krajcik (2008) states that if the students have difficulty in deciding the data that considered as the 
evidence and unable to use the evidence appropriately, students end up using the data that irrelevant to the statements which were made. Another factor is that the students are not adapted to use laboratory tools and materials in collecting data. Jack (2013) states that one of the factors that caused poor observing skills is the lack of laboratory utilization.

Low observational skills are also caused by the lack of concepts mastery. According to the data in Table 4, student learning outcomes were directly proportionated to students' observing skills. HS students have the highest average of learning outcomes (33.79), and LS students have the lowest average learning outcomes (16.67). Danielson (2012) argued that the students' observing skills and other science basic skills became the basis of problem-solving skills. Students with high science process skills could systematically analyse the problem and promote more gain of understanding.

Learning activities of the first cycle were focused on the topic circulatory system, designed to follow the steps of guided inquiry. Students were asked to observe the blood-smear specimens to identify the components of the blood. The teacher changed the learning approach to inquiry-based learning and organized the instructions so that the students could observe properly. Students were working in groups. In the first cycle, students' observing skill of HS students were increased by 17.14, MS students were increased by 22.61, and LS students were increased by 25.59. The most significant progress was seen in the LS group, followed by the MS group. While the LS group has increased less than 20. Improvement of ability that occurs in MS and LS groups were expected due to several factors including the spirit to compete. Low achievement students tend to experience more rapid improvement than high achievement students if they were in the same class (Aktamis \& Ergin, 2008).

LS group were able to identify the differences between blood in the term of colour and texture, while HS group are able to identify the differences in term of colour, texture, and smell. LS group use one sense to observe, while HS group use two senses. LS group were also able to identify detailed differences blood cell's shape, while HS group were able to identify blood centrifuge layers, and differences in colour and shape of blood cells. Both of group able to use microscope correctly, but the LS group still need some assistance to find the right magnification. HS group were able to collect two relevant data, while LS group only able to collect one relevant data.

Based on the results of the reflection of the first cycle, the main problem that occurs was the students were having difficulty in getting used to the guidedinquiry learning. Students have not yet can construct their concepts because they were accustomed to getting the knowledge from the teachers and books. Students were also still having difficulty in writing the result of observations and filling out their worksheets. Improvements suggestion for the next cycle were to explain to the students how to observe and skills that must be mastered before the data collection. This action is based on the opinion of Friesen \& Scott (2008) that guidance from teachers was required in guided inquiry learning in order to train the student mastering the learning goals (Byers, 2015). 
According to Zion \& Mendelovici (2012), instructions should be given at certain levels and reduced gradually to improve the ability of the students. Instructions can lead to effective learning, better students' progress, and motivating the students to correct their mistakes. Teachers can help the students by providing the worksheets, listening to students' observation results and encouraging the students to describe and explain the details of the objects as much as possible (Danielson, 2012).

Learning in the second cycle was a discussion on the types of the blood, and there was also an experiment of blood-test. The teacher added some attractive questions on the students' worksheets to motivate students to seek information apart from the results of the observations. The progress of students' observing skill in the second cycle showed that LS group was increased 21.75, MS group was increased by 21.14, and LS group was increased by 26.78. The skill improvement in the second cycle was the most significant improvement compared to other cycles.

Both of LS and HS group were adequate to identify the differences between blood group, using two right senses to observe the object and identification of the detailed differences. HS group able to use the tools and know the function well, while LS group still need some guidance to use the tools. HS group able to collect all of the relevant data and able to find the reason, while LS group only able to collect data from the observed object.

Students' observation skills in the second cycle were significantly improved compared to the first cycle. Students could identify the differences and the similarity of the objects. Students used some appropriate senses to observe bloodsmear specimen. Students could identify the differences in detail although with the help of the teacher and be able to determine whether an object is more similar or different from the others. Students could collect the relevant data. Students also could connect the results of the experiments with the theories from books and the Internet. But, the students' proficiency in using tools were decreased. Students were less confident and very careful to use the provided tool.

The problem of the second cycle was the decline in the mastering of the skill of using the tools to aid the observation; this was because students not yet have scientific attitudes and not yet accustomed to carrying out the scientific method. Attitudes that need to be trained included confidence, honesty, responsibility, and cooperation (Akinbobola \& Afolabi, 2010). Psychological factors, such as unconsciousness about their cognition, the fright of shame, or anxiety, made the students reluctant to be involved in the learning process so that skills mastery of using the tool is not optimal (Chin \& Chia, 2006).

The improvement of students' observing skill in the second cycle was due to wellorganized instruction by the teacher who had improved the classroom atmosphere more conducive, and the interactions and in-group cooperation among students became more intense. Besides developing the social skills by the interaction among the students, guided inquiry learning could also develop students' thinking skills such as problems solving and constructing the concept. The construction of the concept coherent with the theory of constructivism, that not only the teacher 
provided the knowledge to the students, but also the students must build their own knowledge (Sidiq, et al., 2010)

According to Akinbobola \& Afolabi (2010), improvement of students' observing skills was because of the students involved in activities in the classroom. Guided inquiry can accommodate students to find out their concepts and improve students' cognitive abilities. Zaini (2009) added that the inquiry learning can encourage learners to take part in all the learning processes, mentally and physically. The students will be easy to remember and understand their own independently gained knowledge much longer, compared when the information was got from listening to others.

The subject matter was also affecting the students' skills related to the natural characteristics of the material being studied (Chin \& Osborne, 2010). Learning content that close to everyday life such as blood-type, prompting students to be more interested in learning so it could improve students' observing skills. Dimyati \& Mudjiono (2009) added that psychological and physical conditions were affecting the motivation to learn so could affect the students' process skills in learning.

The third cycle topic was the measurement of pulse rate and human blood pressure. Students' observing skill in the third cycle has undergone some improvement, The HS students were increased by 14.36, The MS students were increased by 17.86, and the LS students were increased by 15.39. Students' observing skill in the last cycle showed that the students have undergone improved observing skills. The skills of identifying differences and object equations were had been well developed. Students were already accustomed to using multiple senses for observation, and able to identify objects in detail, also to show whether the object was more similar or different from other. Students could also use the tools, so the students have been able to use the proper tool to aid observation. Students could collect the data from the latest sources via the Internet, books, and discussions with other groups.

Improvement in the students' observing skill is due to habituation. Observing activities from pre-cycle to the third cycle familiarise the students with observing the objects. Students were getting used to the processes and knew which must be considered, recorded, and written in their worksheets. Domuracki, et al. (2015) states that the activities that guide the students to make observations, encourage the students to explain the results of the observations, reflect the shortcomings of their observations, and repeat the observations on the different objects will improve the students' observing skill.

Improvement of the students' observing skill was also accompanied by improvement of the students' learning outcomes. The HS group the average student learning outcomes were increased by 1.21 , the MS students were increased by 3.16, and the LS students' learning outcomes were increased by 7.43. It can be expected that improvement of the students' observing skills could improve student learning outcomes (Akinbobola \& Afolabi , 2010).

Ketpichainarong, et al. (2010) added that the scientific inquiry undertakes by the students to find out solutions to problems could train the students to be a scientist 
by training the ability to collect scientific evidence, using the relevant literature, and build concepts from strong evidence. This activity can encourage the students to get information or evidence through their observations to find out the solutions to the problems (Banchi \& Bell, 2008).

At the orientation stage of guided inquiry, the students do activities to observe and identify the phenomena or problems presented by the teacher (Kuhlthau, et. al, 2007). According to Lee (2012), the questions and media provided by the teacher in the orientation stage can help students to gather information and build the main topics of the issues based on evidence or observed phenomena.

The stage of formulating the hypotheses was based on students' initial knowledge and observation of the events or phenomena. Initial knowledge of events obtained from observations affects the students' ability to formulate the hypotheses (Sheeba, 2013). Formulating the hypotheses train students to think critically and test their understanding based on the observations at the orientation stage (Ozgelen, 2012).

The data collecting was the main stage that engages the students to hone their observing skills, because in this phase students were required to master observing skills, from the skills to find differences and similarities and detailed characteristics of the objects; determine the relevant data; using multiple senses; using proper tools to aid the observation; and determine whether an object has more similarity or difference from other objects (Harlen, 2014).

\section{CONCLUSIONS}

The results showed there was an improvement in the students' observation skills after the application of guided inquiry learning model. The previously student with poor observing skills can be optimized at the end of the research and have achieved good category (score 3). Students with low observing ability at the start of the research were also showed to have the low academic ability. After experienced the learning process using guided inquiry in three cycles, the LS students showed significant skill improvement compared to HS and MS students.

Using a different object of learning, different practicum, an assessment of the level of difficulties increased and detail worksheet in each cycle resulted in better students' observing skills. More innovative in providing essential questions motivated the students to learn more. It is also important to provide objects that stimulated students' senses and provide detailed worksheets with questions that encourage the students to seek complete and relevant information.

\section{REFERENCES}

Akinbobola, A. O., \& Afolabi, F. (2010). Analysis of Science Process Skills in West African Senior Secondary School Certificate Physics, 4(1), 32-47.

Aktamis, H., \& Ergin, O. (2008). The Effect of Scientific Process Skills Education on Students' Scientific Creativity, Science Attitudes, and Academic Achievements. Asia Pacific Forum on Science Learning and 
Teaching, $\quad 9(1), \quad 21 . \quad$ Retrieved from http://search.proquest.com/docview/61875613?accountid=14719

Ambarsari, W., \& Santosa, S. (2013). Penerapan Pembelajaran Inkuiri Terbimbing Terhadap Keterampilan Proses Sains Dasar Pada Pelajaran Biologi Siswa Kelas VIII SMP Negeri 7 Surakarta. Jurnal Pendidikan Biologi, 5(1), 81-95.

Banchi, H., \& Bell, R. (2008). Many Levels of Inquiry. Science and Children. $1(1), 1-29$.

Bodrova, E., \& Leong, D. J. (2015). Vygotskian and Post-Vygotskian Views on Children's Play. American Journal of Play, 7(3), 371-388. Retrieved from http://www.journalofplay.org/sites/www.journalofplay.org/files/pdfarticles/7-3-article-vygotskian-and-post-vygotskian-views.pdf

Byers, S. (2015). 2015 Experienced Teacher Action Research Pilot Project. ISTTA, (August 2014).

Chin, C., \& Chia, L. G. (2006). Problem-based learning: Using ill-structured problems in biology project work. Science Education, 90(1), 44-67. http://doi.org/10.1002/sce.20097

Chin, C., \& Osborne, J. (2010). Students' questions and discursive interaction: Their impact on argumentation during collaborative group discussions in science. Journal of Research in Science Teaching, 47(7), 883-908. http://doi.org/10.1002/tea.20385

Danielson, C. (2012). Observing Classroom Practice. Educational Leadership, 70(3), 32-37.

Dimyati, \& Mudjiono. (2009). Belajar dan Pembelajaran. Jakarta: Rineka Cipta.

Domuracki, K., Wong, A., Olivieri, L., \& Grierson, L. E. M. (2015). The impacts of observing flawed and flawless demonstrations on clinical skill learning. Medical Education, 49(2), 186-192. http://doi.org/10.1111/medu.12631

Friesen, S., \& Scott, D. (2013). Inquiry-Based Learning: A Review of the Research Literature. Alberta Ministry of Education, (June), 32. Retrieved from http://galileo.org/focus-on-inquiry-lit-review.pdf

Harlen, W. (2014). Helping children's development of inquiry skills. Inquiry in Primary Science Education, 1, 5-19.

Jack, G. U. (2013). The Influence of Identified Student and School Variables on Students' Science Process Skills Acquisition. Journal of Education and Practice, 4(5), 16-23.

Karamustafaoğlu, S. (2011). Improving the Science Process Skills Ability of Science Student Teachers. Eurasian Journal of Physics and Chemistry Education, 3(1), 26-38.

Kemmis, S and R.Mc Taggart (2005). The Action Research Planner. Victoria Deakin University.

Ketpichainarong, W., Panijpan, B., \& Ruenwongsa, P. (2010). Enhanced learning of biotechnology students by an inquiry-based cellulase laboratory. International Journal of Environmental \& Science Education V O L, 5(2), 169-187.

Kuhlthau, C. C., Maniotes, L. K., \& Caspari, A. K. (2007). Guided Inquiry Learning in the 21st century. London: Libraries Unlimited. 
Lee, V. S. (2012). Inspiration and intellect: Significant learning in musical forms and analysis. New Directions for Teaching and Learning, (119), 35-41. http://doi.org/10.1002/tl

McNeill, K. L., \& Krajcik, J. (2008). Inquiry and Scientific Explanations: Helping Students Use Evidence and Reasoning. Science as Inquiry in the Secondary Setting, 121-134.

Nurochmah, T. (2008). Pengaruh Pendekatan Inkuiri terhadap peningkatan Keterampilan Proses Sains Siswa dalam Proses Pembelajaran IPA Biologi pada Materi Pokok Sistem Pencernaan Manusia (STUDI. Yogyakarta)

Ozgelen, S. (2012). Students' science process skills within a cognitive domain framework. Eurasia Journal of Mathematics, Science and Technology Education, 8(4), 283-292. http://doi.org/10.12973/eurasia.2012.846a

Rankin, L. (2006). Assessing for Learning Facilitator's Guide Workshop II : Assessing Process Skills a Professional Development Curriculum from the Institute for Inquiry.

Riyadi, I. P., Prayitno, B. A., \& Marjono. (2015). Penerapan Model Pembelajaran Inkuiri Terbimbing (Guided Inquiry) pada Materi Sistem Koordinasi untuk Meningkatkan Keterampilan Proses Sains pada Siswa Kelas XI IPA 3 SMA Batik 2 Surakarta Tahun Pelajaran 2013/2014. Jurnal Pendidikan Biologi, 7, 108-118.

Rustaman, N. (2003). Kemampuan Proses Ilmiah dalam Pembelajaran Sains. Bandung: Universitas Pendidikan Indonesia Press.

Sheeba, M. N. (2013). An Anatomy of Science Process Skills In The Light Of the Challenges to Realize Science Instruction Leading To Global Excellence in Education. Education Confab, 2(4), 108-123.

Sidiq, Y., Prayitno, B. A., Karyanto, P., \& Sugiharto, B. (2012). Pengaruh Strategi Pembelajaran Instad Terhadap Keterampilan Proses Sains. Prosiding Seminar Biologi, 9(1), 305-309. Retrieved from http://www.jurnal.fkip.uns.ac.id/index.php/prosbio/article/view/1094

Şimşek, P., \& Kabapinar, F. (2010). The effects of inquiry-based learning on students' conceptual understanding of matter, scientific process skills and science attitudes. Procedia - Social and Behavioral Sciences, 2(2), 11901194. http://doi.org/10.1016/ j.sbspro.2010.03.170

Stone, E. M. (2014). Guiding Students to Develop an Understanding of Scientific Inquiry: A Science Skills Approach to Instruction and Assessment. CBE Life Sciences Education, 13, 90-101. http://doi.org/10.1187/cbe-12-11-0198

Sutman, F. X., Schmuckler, J. S., \& Woodfield, J. D. (2008). The Science Quest Using Inquiry/Discovery to Enhance Student Learning. San Francisco: Jossey Bass.

Zaini, H. (2009). Strategi Pembelajaran Aktif. Seminar Lokakarya Nasional Pendidikan Biologi FKIP UNS, 1-9.

Zion, M., \& Mendelovici, R. (2012). Moving from structured to open inquiry: Challenges and limits. Science Education International, 23(4), 383-399. 
